\title{
REVIEW
}

\section{Clock genes in health and diseases}

\author{
Valérie Mongrain $^{1,2,3}$, Nicolas Cermakian ${ }^{1,2}$ \\ ${ }^{1}$ Laboratory of Molecular Chronobiology, Douglas Mental Health University Institute, Montréal, Canada \\ ${ }^{2}$ Department of Psychiatry, McGill University, Montréal, Canada \\ ${ }^{3}$ Present address: Center for Integrative Genomics, University of Lausanne, Switzerland
}

Received $29^{\text {th }}$ January 2009.

Published online $11^{\text {th }}$ March 2009.

\begin{abstract}
Summary
Circadian rhythms, rhythms of about $24 \mathrm{~h}$ in various physiological functions, are getting extensively characterized at the molecular level. The generation of circadian rhythms is acknowledged to originate from oscillations in the expression of several clock genes as well as in the regulation of their protein products. While the general entrainment of organisms to the light-dark cycle of the environment is mainly achieved through the master clock of the suprachiasmatic nucleus in mammals, the molecular clockwork is functional in various organs and tissues. The molecular components of the circadian system have been found to be essential for a diversity of basic and homeostatic systems ranging from the control of cell cycle, the regulation of cardiac and metabolic function, to the fine-tuning of sleep and mental health. The present review will focus on the involvement of clock genes in human health and diseases.
\end{abstract}

Key words: clock genes; peripheral clocks; circadian rhythms; human; sleep disorders; psychiatric disorders; cancer; metabolism

\section{INTRODUCTION}

Biological rhythms evolved to adapt to the rotation of the Earth. Rhythms with a period of about 24 hours termed circadian rhythms - are everywhere in biology from single-cell organisms to more

Nicolas Cermakian, Douglas Mental Health
University Institute, 6875 LaSalle blvd.,
Montreal, QC, H4H 1R3, Canada
nicolas.cermakian@mcgill.ca
1-514-761-6131 ext 4936

complex organisms such as mammals (Dunlap et al. 2004). Besides their period, a second property of circadian rhythms resides in their endogenous origin; these rhythms are sustained even in the absence of time cue. Thirdly, circadian rhythms have the capacity to synchronize with the environment (via synchronisers or "Zeitgebers"). In the present review, we will describe the links between elements of the molecular machinery governing circadian rhythms and various physiological functions in mammals. We will put emphasis on the involvement of the "clock genes" in health and evidence of their dysfunction in various diseases (Table 1). 
Mongrain and Cermakian: Clock genes in health and diseases

Table 1. Selected literature linking clock genes to human health or diseases

\begin{tabular}{|c|c|c|c|}
\hline Health dimension & Genes & Involved in & References \\
\hline \multirow[t]{6}{*}{ Sleep timing } & Clock & Diurnal preference and DSPD & $\begin{array}{l}\text { Katzenberg et al. } 1998 \text {, } \\
\text { Iwase et al. } 2002, \\
\text { Robilliard et al. } 2002 \text {, }\end{array}$ \\
\hline & Perl & Extreme diurnal preference & Carpen et al. 2006, \\
\hline & Per2 & ASPD & $\begin{array}{l}\text { Toh et al. 2001, } \\
\text { Vanselow et al. 2006, } \\
\text { Xu et al. } 2007 \text {, }\end{array}$ \\
\hline & Per3 & Diurnal preference and DSPD & $\begin{array}{l}\text { Archer et al. 2003, } \\
\text { Pereira et al. 2005, } \\
\text { Jones et al. 2007, }\end{array}$ \\
\hline & $C K I \delta$ & ASPD & $\mathrm{Xu}$ et al. 2005 , \\
\hline & $C K I \varepsilon$ & DSPD & Takano et al. 2004. \\
\hline \multirow[t]{6}{*}{ Sleep homeostasis } & Clock & Sleep duration, REM rebound & Naylor et al. 2000, \\
\hline & Npas2 & Sleep amount, activity rhythms & Dudley et al. 2003, \\
\hline & & Sleep EEG regulation & Franken et al. 2006, \\
\hline & Cryl/2 & Sleep duration, delta regulation & Wisor et al. 2002, \\
\hline & Perl $1 / 2, D b p$ & Recovery sleep regulation & $\begin{array}{l}\text { Franken et al. 2007, } \\
\text { Wisor et al. 2002, 2008, }\end{array}$ \\
\hline & Per3 & Sensitivity to sleep pressure & Viola et al. 2007. \\
\hline Sleep apnea & Perl & Changed in PBMCs of patients & Burioka et al. 2008. \\
\hline \multirow[t]{11}{*}{ Psychiatric diseases } & Clock & Modulation of DA regulation & McClung et al. 2005, \\
\hline & & Response to cocaine in brain & Uz et al. 2005, Lynch et al. 2008, \\
\hline & Npas 2 & Regulation of MAOA & Hampp et al. 2008, \\
\hline & Bmall & Response to cocaine in striatum & Lynch et al. 2008 , \\
\hline & & Changed in bipolar disorder & Yang et al. 2009 , \\
\hline & & Regulation of MAOA & Hampp et al. 2008 \\
\hline & Perl & Reward pathway & Angeles-Castellanos et al. 2008, \\
\hline & Per2 & $\begin{array}{l}\text { Response to cocaine in brain } \\
\text { Striatum neuronal activity }\end{array}$ & Uz et al. 2005, Lynch et al. 2008, \\
\hline & Cryl & Response to cocaine in striatum & Lynch et al. 2008 \\
\hline & $\operatorname{Rev}-E r b \alpha$ & Changed in bipolar disorder & Yang et al. 2009, \\
\hline & $D b p$ & Changed in bipolar disorder & Yang et al. 2009. \\
\hline \multirow[t]{14}{*}{ Metabolism } & Clock & Lipid and glucose metabolism & $\begin{array}{l}\text { Turek et al. 2005, } \\
\text { Kennaway et al. } 2007 \text {, }\end{array}$ \\
\hline & & $\begin{array}{l}\text { Regulation of PPAR } \alpha \text { and lipid } \\
\text { metabolism }\end{array}$ & $\begin{array}{l}\text { Oishi et al. 2005, } \\
\text { Inoue et al. } 2005\end{array}$ \\
\hline & Bmall & Adipogenesis & Shimba et al. 2005 , \\
\hline & & Changed with high cholesterol & Gomez-Abellan et al. 2008, \\
\hline & & Glucose metabolism & Gatfield and Schibler 2008, \\
\hline & & Type 2 Diabetes & Woon et al. 2007, \\
\hline & Per2 & Changed with high cholesterol & Gomez-Abellan et al. 2008, \\
\hline & Cryl & Changed with high cholesterol & Gomez-Abellan et al. 2008, \\
\hline & $\operatorname{Rev}-E r b \alpha$ & Bile acid production & Duez et al. 2008 \\
\hline & & $\begin{array}{l}\text { Triglyceride and lipid } \\
\text { metabolism }\end{array}$ & Fontaine and Staels 2007, \\
\hline & $\operatorname{Rev}-\operatorname{Erb} \beta$ & Lipid Metabolism in muscle & Ramakrishnan et al. 2005 , \\
\hline & Ror $\alpha$ & Lipid Metabolism in muscle & Lau et al. 2004 \\
\hline & & $\begin{array}{l}\text { Metabolism of steroids, xenobiotics } \\
\text { and bile acids }\end{array}$ & Kang et al. 2007 , \\
\hline & Ror $\gamma$ & $\begin{array}{l}\text { Metabolism of steroids, xenobiotics } \\
\text { and bile acids }\end{array}$ & Kang et al. 2007. \\
\hline \multirow[t]{4}{*}{ Cardiac Function } & Clock & Platelet rhythmic activity & Ohkura et al. 2008, \\
\hline & & $\begin{array}{l}\text { Response of cardiomyocytes to fatty } \\
\text { acids }\end{array}$ & Durgan et al. 2006, \\
\hline & Bmall & Susceptibility for hypertension & Woon et al. 2007, \\
\hline & Per 2 & Aortic endothelial function & Viswambharan et al. 2007 , \\
\hline
\end{tabular}




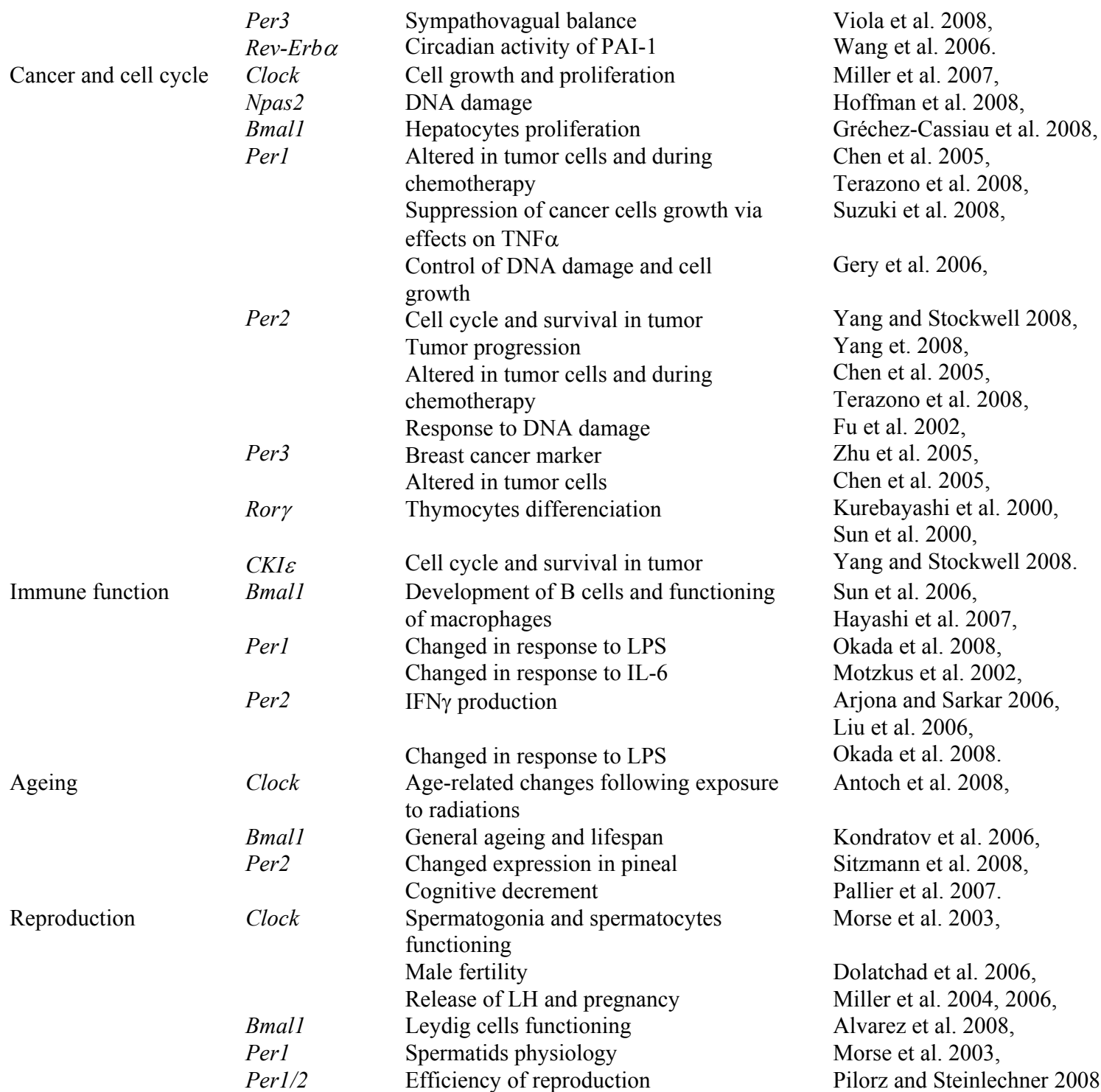

\footnotetext{
Abbreviation: ASPD, advance sleep phase disorder; DA, dopamine; DSPD, delayed sleep phase disorder; IFN $\gamma$, interferon gamma ; IL-6, interleukin 6; LH, luteinizing hormone; LPS, lipopolysaccharides; MAOA, monoamine oxidase A; PAI-1, plasminogen activator inhibitor-1; PBMC, peripheral blood mononuclear cells; PPAR, peroxisome proliferator-activated receptor; REM, rapid eye movement; TNF $\alpha$, tumor necrosis factor alpha.
}

\section{CORE-CLOCK MECHANISMS}

Circadian rhythms originate from molecular regulatory loops of transcription, post-transcriptional modifications, translation and post-translational modifications (Dardente and Cermakian 2007). These feedback loops generate $24 \mathrm{~h}$ rhythms in the levels of messenger RNAs (mRNA) from clock genes and their protein products, as well as in the activity of these clock proteins. In mammals, the core-clock proteins
CLOCK and BMAL1 associate and activate the transcription of many other clock genes (Crys, Pers, Rev-Erbs, Rors) and clock-controlled genes via E-box elements in their promoters (Gekakis et al. 1998, Ueda et al. 2005). The products of these genes then feed back on CLOCK/BMAL1 activity or Clock/Bmall gene transcription (see Fig. 1 for a summary). For example, CRYs and PERs form complexes repressing the activity of the CLOCKBMAL1 heterodimer and therefore repress their own 
transcription (Kume et al. 1999, Sato et al. 2006), whereas nuclear receptors of the REV-ERB and ROR families respectively repress or activate the transcription of Bmall gene (Preitner et al. 2002, Sato et al. 2004, Akashi and Takumi 2005, Guillaumond et al. 2005, Mongrain et al. 2008). Also, the system is regulated by the activity of protein kinases, notably $\mathrm{CKI} \delta / \varepsilon$ and GSK-3, and phosphatases, which controls the association, nuclear translocation and degradation of clock proteins via modulation of their phosphorylation levels (Lowrey and Takahashi 2000,
Gallego et al. 2006, Meng et al. 2008). Adding to the complexity of the molecular circadian machinery is the partial and sometimes tissue-specific redundancy of these clock genes (i.e. Npas2/Clock; Per1/2; Cry 1/2; and possibly Bmal1/2; Reick et al. 2001, Dardente et al. 2007, DeBruyne et al. 2006, 2007) and the presence of other feedback elements such as DEC1-2, which appear to form an additional negative feedback loop with CLOCK/BMAL1 (GréchezCassiau et al. 2004, Hamaguchi et al. 2004, Sato et al. 2004, Nakashima et al. 2008).

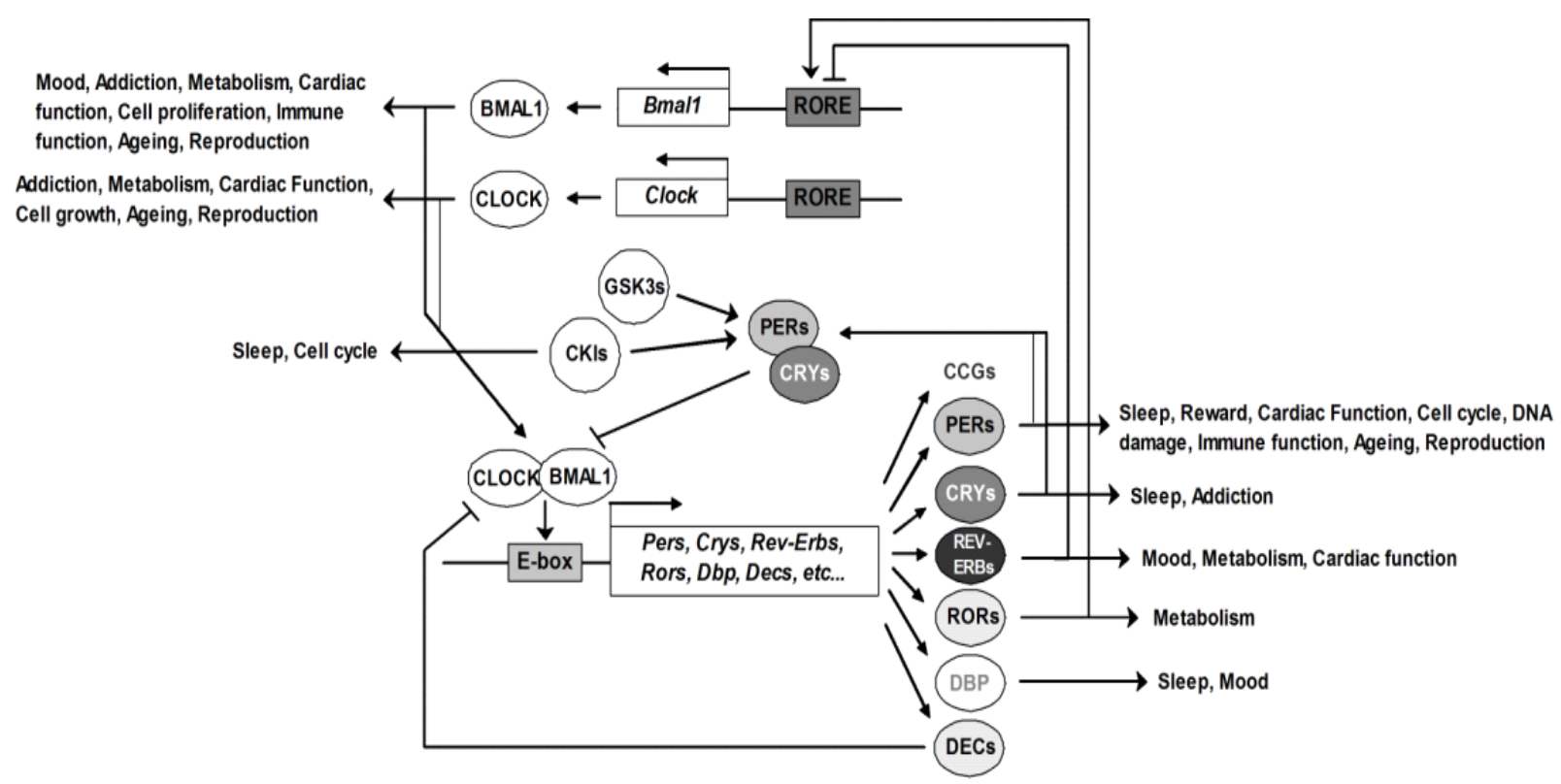

Fig. 1. Schematic view of the circadian clock mechanisms and their association with physiology. The CLOCK/BMAL1 heterodimer activates the expression of a number of clock genes. Among these, Pers and Crys give rise to protein products that inhibit their own expression, while Rev-Erbs and Rors genes products repress or activate the transcription of Clock and Bmall respectively. Evidence showed that these clock components are associated with the normal regulation of sleep, reproduction, psychiatric diseases and mood, cardiac and metabolic function, immune system, cell cycle and proliferation and the ageing process.

The central circadian clock has been localized to the suprachiasmatic nuclei ( $\mathrm{SCN}$ ) of the hypothalamus (Ralph et al. 1990, Silver and Schwartz 2005) and is reset daily by photic inputs from the retina (Hastings and Herzog 2004, Silver and Schwartz 2005). Many other brains regions and peripheral organs have been shown to also express clock genes in a circadian manner (Yamazaki et al. 2000, Reick et al. 2001, Abe et al. 2002, Cermakian and Sassone-Corsi 2002, Schibler et al. 2003, Granados-Fuentes et al. 2004, Yoo et al. 2004, Lamont et al. 2005). Nevertheless, the properties of the different circadian oscillators within an organism appear to differ. The molecular oscillations of individual cells within peripheral tissues desynchronize such that overall tissue rhythm becomes flattened earlier than in the SCN, most likely due to the lack of electrical and/or chemical coupling between cells (Yamazaki et al. 2000, Welsh et al. 2004, Liu et al. 2007a). Also, the synchronization of non-SCN oscillators seems to occur via a wide range of endogenous rhythmic signals (e.g. glucocorticoid, neuronal activity, temperature rhythms) that are mainly dependent on the SCN (Damiola et al. 2000, Reppert and Weaver 2002, Stratmann and Schibler 
2006, Kornmann et al. 2007). Additionally, and consistent with the specific functions of the different organs, tissue-specificity in the expression of clockcontrolled genes has been reported (Panda et al. 2002, Storch et al. 2002, Duffield 2003). A requirement for proper organism functioning and health seems to reside in the synchronisation of the different clocks within the organism, such that internal desynchrony appears to lead to disease. Examples of such health problems due to deregulated rhythms will be highlighted in the present review.

In addition to adjusting the organism to the external time, clock genes are found to be required for homeostatic systems in mammals. For example, mutations of some clock genes (Clock, Npas2, Cry 1/Cry2) were found to modify parameters of the homeostatic regulation of sleep in mice (Naylor et al. 2000, Wisor et al. 2002, Dudley et al. 2003, Franken et al. 2006) and changes in clock gene expression in the forebrain are linked with the homeostatic response of slow-wave activity during sleep in the mouse (Franken et al. 2007, Wisor et al. 2008). A role for clock genes in the reproductive system was also underlined by recent studies. Notably, intact clock genes appear important for normal fertility, successful pregnancy, delivery and weaning (Miller et al. 2004, 2006, Dolatshad et al. 2006, Alvarez et al. 2008, Pilorz and Steinlechner 2008). Whether the clock genes govern these functions independently of their role in circadian timekeeping is unclear given the difficulty to distinguish clock-related from clockunrelated roles.

\section{CLOCKS GENES AND CIRCADIAN OR SLEEP DISORDERS}

Intact clock machinery has been reported to be essential for maintenance and stability of circadian rhythms in rodents (see Cermakian and Boivin 2003 for a review). In humans, some pathological conditions are characterized by the misalignment of the sleep episode relatively to the light-dark cycle. Studies of the biology of clock genes in circadian rhythm disorders (mainly delayed sleep phase disorder and advance sleep phase disorder, DSPD, ASPD) have contributed to understanding their etiology as well as to underline their complexity. Additionally, other sleep disorders have been reported to involve changes in clock genes expression.

More than a decade ago, a single nucleotide polymorphism in the human CLOCK gene was linked to sleep timing preference (Katzenberg et al. 1998). Thereafter, the $T$ allele of this T3111C polymorphism was observed to be weakly associated to late sleep timing or DSPD (Iwase et al. 2002, Robilliard et al. 2002) but not in all populations studied (Pedrazzoli et al. 2007). Similarly, a silent polymorphism in human PERl gene seems to be related to extreme diurnal preference (Carpen et al. 2006). Regarding the PER2 gene, studies have demonstrated that some polymorphisms have no effect on sleep timing (Johansson et al. 2003, Carpen et al. 2005), while one (A2106G) leading to decreased PER2 protein amounts is of great interest in the pathophysiology of ASPD and was shown to be the cause of a familial case of this disorder (Toh et al. 2001, Vanselow et al. 2006, $\mathrm{Xu}$ et al. 2007). The involvement of PER2 polymorphisms in circadian disorders seems to involve changes in PER2 protein phosphorylation levels (Gallego and Virshup 2007). Accordingly, in another family with ASPD, the disorder is caused by a nucleotide change in the $C K I \delta$ gene (Xu et al. 2005), while a polymorphism in $C K I \varepsilon$ was found to associate with DSPD (Takano et al. 2004). Many studies reported data about a variable number tandem repeat polymorphism in the human PER3 gene in relation to diurnal preference or circadian disorders. Overall, the allele with 5 repeats appears to be linked to morningness while the allele with 4 repeats associates with delayed sleep schedule and DSPD (Archer et al. 2003), although this appears to depend on age and latitude (Pereira et al. 2005, Jones et al. 2007). However, subjects specifically selected for their genotype (5/5 and 4/4 individuals) were shown to have similar sleep schedule but to differ in markers of sleep pressure: individuals with the $5 / 5$ genotype show indications of greater sensitivity to sleep deprivation than 4/4 individuals (Viola et al. 2007). Overall, studies in humans and rodents show their importance of functional clock machinery for appropriate sleep timing and sleep homeostasis.

Shift-work sleep disorder (SWSD) has been classified as a circadian and sleep disorder (AASM, 2005) and is most likely the result of misalignment between clocks of different tissues, as well as between circadian clocks and the light/dark cycle. Sleep complaints including excessive daytime sleepiness, poor sleep quality or insomnia are hallmarks of SWSD (Sudo and Ohtsuka 2002, Portela et al. 2004, Paim et al. 2008). But these are only a part of the problems experienced by individuals suffering from SWSD - see Costa (1996) and Schwartz and Roth (2006) for reviews. Other dysfunctions affecting shiftworkers will be treated in the next sections where they serve to reinforce the associations between clock genes and specific health issues. Another example of sleep pathology changing the normal sleep/wake 
pattern is sleep apnea, where hypoxic episode and awakenings during sleep generate very shallow sleep and drastic sleepiness during wakefulness. Recently, PER1 rhythmic expression in peripheral blood cells has been shown to be affected in sleep apnea patients (Burioka et al. 2008). Changes in clock gene expression in sleep apnea might underlie alterations of circadian rhythms in vigilance, sympathetic activity, cortisol metabolism and inflammatory mediators in these patients (Andreas and Eichele 2008). Moreover, the susceptibility of these patients to cardiovascular disease may result, at least in part, from such changes in central or peripheral clock mechanisms, as discussed in a subsequent section.

\section{CLOCK GENES AND OTHER PSYCHIATRIC DISORDERS}

Links have been reported between the molecular components of the circadian system and psychiatric disorders such as schizophrenia, Alzheimer's disease, major depressive disorder, bipolar disorder, anxiety disorder, drug addiction and alcoholism. Evidence for such links resides in the observations of changes in circadian functions or sleep as well as modifications of clock gene sequence and expression. Since these evidence were recently reviewed in details (Lamont et al. 2007, McClung 2007a, Turek 2007, Barnard and Nolan 2008), only an overview of the latest findings will be provided here.

Interestingly, bipolar disorder has been associated with a reduced circadian amplitude in clock genes expression (e.g. BMAL1, REV-ERB $\alpha, D B P$ ) and reduced phosphorylated levels of GSK3 $\beta$ in fibroblasts from patients (Yang et al. 2009). Also, a possible mechanism for normal circadian changes in mood as well as for the link between clock genes and mood disorders was revealed in recent work showing that the regulation of monoamine oxidase A (a key enzyme in dopamine metabolism) was under the control of the clock proteins BMAL1, NPAS2 and PER2 (Hampp et al. 2008). This study also reported that mutation of Per2 in animals leads to reduced neuronal activity in the striatum and to reduced monoamine oxidase A activity in the mesolimbic dopaminergic system, which is particularly relevant to mood regulation but also to the reward/addiction system.

Robust associations between drug addiction and molecular circadian clocks were also highlighted. First, self-administration of drug of abuse shows circadian variations in rats with a peak of cocaine administration during the active period (Lynch et al. 2008). Of note, the sensitization to cocaine administration also shows a time of day-dependent effect in rodents (Akhisaroglu et al. 2004). Second, repeated administration of cocaine alters the expression of many clock genes in rat and mouse brains. For example, a single or a repeated exposure to cocaine differentially increases the expression of different clock genes (Per 1, Per2, Per3, Clock) in the hippocampus and the striatum (Uz et al. 2005). Also, self-administration of cocaine up-regulates the expression of Bmall, Clock, Cryl and Per2 in the rat striatum (Lynch et al. 2008), indicating that the chronic effects of cocaine consumption could be mediated by changes in clock components in various brain regions. Related observations were also made with other responses of the reward pathway, such as for food or chocolate (Angeles-Castellanos et al. 2008). Third, an intact CLOCK protein appears also important for proper dopamine biosynthesis since increased expression and phosphorylation of tyrosine hydroxylase have been observed in the Clock mutant mouse and this in combination with an increase in cocaine reward and excitability of dopamine neurons of the midbrain ventral tegmental area (McClung et al. 2005). Fourth, exposure to drug of abuse appears to entrain circadian oscillators in the body independently of the signals from the master SCN clock (Kosobud et al. 2007). Evidence regarding the involvement of circadian genes in drug sensitivity and sensitization especially by way of the mesolimbic dopaminergic system have been reviewed recently (McClung 2007b) as well as the effects of drug of abuse on the expression of clock genes (Perreau-Lenz and Spanagel 2008).

\section{CLOCKS GENES AND METABOLISM}

Considerable evidence points towards the involvement of molecular clock components in the regulation of metabolism, as well as the responsiveness of the clock to metabolic challenges. Increased metabolic dysfunctions are associated with circadian disorganization, for example in shiftworkers or in animals with a deficient circadian clock. Indeed, lipid metabolism seems to be impaired when eating is redistributed during night shifts, as higher LDL cholesterol and higher triacylglycerol have been reported with night food intake in humans (Lennernäs et al. 1994, Holmbäck et al. 2002). These are the main characteristics of the so-called metabolic syndrome experienced by night workers along with a higher body mass index than day workers (Biggi et al. 2008, 
Copertaro et al. 2008). Also, hallmarks of metabolic syndrome, such as high LDL and total cholesterol levels, are associated with decreased expression of $B M A L 1, P E R 2$ and $C R Y 1$ in human adipose tissue (Gomez-Abellan et al. 2008). Finally, a BMAL1 haplotype associates with type 2 diabetes in human (Woon et al. 2007).

Work on animals with mutation in clock genes has led to similar observations. Notably, obesity and metabolic syndrome have been reported in Clock mutant animals (Turek et al. 2005). According to theses observations, Clock would be an important regulator for lipids but also for glucose metabolism as hyperglycemia and hypoinsulinemia are associated with the metabolic syndrome of Clock mutant mice (Turek et al. 2005), although less drastic effects were found on a different genetic background (Oishi et al. 2006). Also, mutations of Clock or Bmall has been linked to defect in glucose metabolism (Rudic et al. 2004) even when these mutations are restricted to specific peripheral tissues (Kennaway et al. 2007, Gatfield and Schibler 2008, Lamia et al. 2008).

In the liver, the effects of the circadian molecular machinery on lipid metabolism was shown to result from the circadian regulation of key lipid-metabolism players such as low-density lipoprotein receptor and polypeptide-1 (Kudo et al. 2008). Also, data support a role for nuclear receptors in linking circadian clocks and metabolism (Bookout et al. 2006, Yang et al. 2006). An example is the control of bile acid production by REV-ERB $\alpha$ (Duez et al. 2008). In fact, $\mathrm{REV}-\mathrm{ERB} \alpha$ is an essential regulator of metabolic reactions as it is involved in lipid metabolism, adipogenesis and energy balance - see Duez and Staels (2008) for a review. Nuclear receptors of the ROR family, particularly ROR $\alpha$ and ROR $\gamma$, were also found to be involved in numerous metabolic pathways as those of steroids, xenobiotics and bile acids production (Kang et al. 2007). Moreover, ROR $\alpha$ and $\mathrm{REV}-\mathrm{ERB} \alpha$ are transcriptional regulators of factors involved in triglyceride and lipoprotein metabolisms (i.e. ApoC-III and ApoA1, Fontaine and Staels 2007) while ROR $\alpha$ and REV-ERB $\beta$ have a similar role for lipid metabolism components in skeletal muscle (Lau et al. 2004, Ramakrishnan et al. 2005).

Other important nuclear receptors are those of the Peroxisome proliferator-activated receptor (PPAR) family, which regulate lipid and glucose metabolisms as well as inflammatory processes. Indeed, data showed that the expression of PPAR $\alpha$ is regulated by CLOCK-BMAL1 (Oishi et al. 2005) and that this regulation is directly involved in lipid metabolism (Inoue et al. 2005). Data suggest that significant crosstalk with PPAR nuclear receptors are mediated by REV-ERB $\alpha$, placing it at a strategic position for circadian regulation of energy homeostasis (Duez and Staels 2008). Lastly, the link between the circadian system and lipid regulation by way of PPAR also appears to be bidirectional as the molecular clock machinery is shown to be affected by mediators of lipid homeostasis and the PPAR pathway (Nakahata et al. 2006, Shirai et al. 2006, 2007, Nakamura et al. 2008).

Additional support to the involvement of nuclear receptors in bridging circadian rhythms and metabolism come from studies in which the disruption of the function of coactivators - e.g. PGC-1 $\alpha$ or PGC$1 \beta$ (Liu et al. 2007b, Sonoda et al. 2007) - or corepressors - e.g. NCoR/HDAC3 (Alenghat et al. 2008) - of nuclear receptors was shown to alter behavioural circadian rhythms and metabolic processes.

\section{CLOCKS GENES AND CARDIAC FUNCTION}

Clock components have been linked to the proper functioning of the cardiovascular system either directly or via their effects on metabolism. Initial evidence were provided by the observations of an increased risk of cardiovascular events (e.g. stroke, sudden cardiac death, myocardial infarction, ventricular arrythmias) at specific clock times, notably between 6 AM and noon (Muller et al. 1987, Siegel et al. 1992, Eksik et al. 2007, Shea et al. 2007, Kawakami et al. 2008). Moreover, individuals submitted to circadian misalignment are more at risk of developing cardiovascular problems. Accordingly, shift work has recently been observed to increase the probability of developing atherosclerosis and myocardial infarction at a younger age (Haupt et al. 2008) and to exacerbate the negative effects of high blood pressure on coronary heart diseases (Virkkunen et al. 2007). Other studies revealed that shift workers present more risk than daytime workers of undergoing coronary heart diseases, hypertension, and cerebrovascular incidents (Boggild and Knutsson 1999, Ellingsen et al. 2007). Even a single night shift was recently shown to increase blood pressure and heart rate as well as to reduce heart rate variability in shift workers ( $\mathrm{Su}$ et al. 2008). Circadian disorganization has also been associated with increased cardiovascular diseases in rodents (Martino et al. 2008), and altered clock gene expression in cardiovascular organs (Martino et al. 2007). On the whole, these data show that appropriate circadian alignment is necessary to maximize cardiovascular health. 
How the molecular components of the circadian clocks and particularly how the precise synchronization or desynchronisation between peripheral oscillators could contribute to cardiovascular health or dysfunction, respectively, was the topic of a detailed recent review (Young and Bray 2007). The link between circadian clock and cardiac health seems to be multifactorial. Among the factors, many cardiovascular components and mediators have been found to be clock-regulated. Notably, the circadian rhythm in platelet activity has been reported to depend on the core-clock component CLOCK (Ohkura et al. 2008), whereas the expression of plasminogen activator inhibitor-1, a major contributor to fibrinolysis, also seems to be clockregulated (Naito et al. 2003, Wang et al. 2006). Orphan nuclear receptors also seems to be involved in coupling cardiac physiology to circadian rhythms since PPAR $\gamma$ was recently shown to control circadian variations in blood pressure and heart rate via the control of the Bmall gene (Wang et al. 2008). Finally, genetic variations in clock genes were linked to specific cardiovascular phenotype. Particularly, haplotypes for the core-clock gene Bmall have recently been associated with hypertension in both human and rodents (Woon et al. 2007). Moreover, the cardiac autonomic response, more precisely the sympathovagal balance during sleep, depends on the variable number tandem repeats polymorphism in the PER3 gene (Viola et al. 2008). Therefore, the molecular clock appears highly relevant to cardiovascular physiology.

\section{CLOCKS GENES AND CANCER}

One of the most striking associations between circadian rhythms and health relates to cancer. Epidemiological studies have showed an increased incidence of cancer in shift-workers or individuals chronically submitted to jet lag (Hansen 2001, Rafnsson et al. 2001, Buja et al. 2006, Viswanathan et al. 2007). Moreover, increased light levels at night have been observed to co-distribute with breast cancer in women (Davis et al. 2001, Reiter et al. 2007, Kloog et al. 2008). The expression of clock genes in cancer patients undergoing surgery have been reported to be changed (Azama et al. 2007). Also, the expression of clock genes is changed in tumor cells (Filipski et al. 2005, You et al. 2005) and, more precisely, some tumor show altered PER gene expression likely due to changes in promoter sequence (Chen et al. 2005).
Furthermore, the association between clock genes and cancer resides not only in the fact that a good circadian synchronization and intact circadian machinery are important for cancer prevention but also in the observation that the occurrence of cancer generates a circadian dysfunction, which itself can exacerbate cancer state. Accordingly, circadian rhythms disruption was shown to increase tumor growth (Filipski et al. 2002, 2003, 2004, Otálora et al. 2008). On the other hand, greater amplitude of circadian rhythms in human, as indexed by rest/activity or cortisol rhythms, was associated with increased survival to cancer (Mormont et al. 2000, Sephton et al. 2000), and the response to chemotherapy have been shown to depend on the phase of the circadian cycle with better tumor regression, higher survival rate and less side effects when the therapeutic agents are given at specific circadian time (Gorbacheva et al. 2005, Iurisci et al. 2006, Wood et al. 2006, Lévi et al. 2008). Nevertheless, side effects of chemotherapy are observed on the clock machinery, notably in reducing the amplitude of Per gene expression (Terazono et al. 2008), which might in turn contribute negatively to the association between circadian disruption and tumor progression.

What mechanisms are behind this control of tumors by the circadian system? The circadian control of the cell cycle is a likely route for this control (Chen and McKnight 2007, Lévi et al. 2007). Indeed, the cycle of cell division of normal and cancer cells has been reported to be under circadian control as clockcontrolled genes are involved in the cell cycle and in cell proliferation, including Wee1, c-Myc and p21 (Matsuo et al. 2003, Fu et al. 2002, 2005, Granda et al. 2005, Wood et al. 2006, Gréchez-Cassiau et al. 2008, Dagenais-Bellefeuille et al. 2008). Of note, CKI $\varepsilon$ and PER2 appear to be particularly important for cell cycle and cell survival in tumor cells (Yang and Stockwell 2008). Also, mutation of Clock decrease cell growth and proliferation in fibroblasts (Miller et al. 2007), while the proliferation of hepatocytes from Bmall KO mice is slowed down compared to wild-type counterparts (Gréchez-Cassiau et al. 2008).

Among clock components, Per genes appear central for their involvement in cancer mechanisms. First, a genetic variation in the PER3 gene was proposed as a marker of breast cancer in young women (Zhu et al. 2005). Second, PER genes have been reported to act as tumor suppressors (Lee 2006), given that Perl and Per2 are potential modulator of DNA damage (Fu et al. 2002, Gery et al. 2006). Third, recent studies showed that on one side Perl is 
involved in the suppression of cancer cells proliferation via TNF- $\alpha$ (Suzuki et al. 2008) while on the other hand that Per2 is crucial to prevent tumorigenesis (Yang and Stockwell 2008, Yang et al. 2008). Despite the evidence supporting an antitumoral role of clock components, disruption of the circadian timing system produced by mutation of Cry 1 and $C r y 2$ does not increase cancer predisposition or DNA damage by itself (Gauger and Sancar 2005). This suggests that not any disruption of clock function leads to tumorigenesis.

The links between the molecular biology of circadian rhythms and cancer could also be mediated, at least in part, by the circadian regulation of the immune system. The circulating levels of some immune cells (e.g. neutrophils, monocytes, lymphocytes) and cytokines (e.g. interleukin-2, 10, tumor necrosis factor- $\alpha$ ) in the blood show circadian rhythmicity (Young et al. 1995, Born et al. 1997) as is the case for phagocytosis by neutrophils (Hriscu 2005). Also, data from mutant mice strongly support a role for Bmall in B cell development and macrophage function (Sun et al. 2006, Hayashi et al. 2007) and for the implication of Per 2 in the circadian control of interferon- $\gamma$ production (Arjona and Sarkar 2006, Liu et al. 2006). Additionally, mediators of the immune response have been shown to influence clock gene expression. Notably, inteleukin-6 was shown to induce PERl expression in human hepatoma cells (Motzkus et al. 2002), and tumor necrosis factor- $\alpha$ suppresses the expression of several clock genes in the liver and alters locomotor activity rhythms (Cavadini et al. 2007). Recently, lipopolysaccharide injection was found to blunt expression of Perl and Per 2 transcripts in both the SCN and the liver (Okada et al. 2008). Lastly, some studies showed that symptoms of inflammatory disease display circadian variations (Cutolo et al. 2003), while the hematopoietic lineage per see seems to be regulated in a circadian fashion (Berger 2008, Méndez-Ferrer et al. 2008).

\section{CLOCK GENES AND AGEING}

The molecular machinery of circadian clocks is also relevant to ageing and particularly to the age-related decrement in circadian amplitude, memory and cognitive function. It is well known that aged humans experience reduced amplitude in circadian rhythms of activity, core body temperature, melatonin secretion and EEG circadian hallmarks (Cajochen et al. 2006).
Moreover, recent literatures supports the involvement of the central circadian clock in age-dependent changes in neuronal function. For example, data suggest that distinct neuronal populations of the SCN are implicated in different functional modifications in human dementia, as activity and temperature rhythms (Harper et al. 2008). In rats, the temporal relationship between the main circadian clock and peripheral oscillators appears modified with age (Yamazaki et al. 2002), and resetting of internal circadian clocks following phase shifts are modified in aged rats such that the synchrony between clocks is reduced (Davidson et al. 2008). In primates, age was shown to affect clock gene expression in pineal gland (Sitzmann et al. 2008). Mice mutant for the core clock component BMAL1 exhibit many signs of premature ageing in combination with a reduced lifespan (Kondratov et al. 2006). Similarly, recent data also showed that Clock mutant animals accelerate their ageing process following exposure to radiation as indexed by increased amount of hyperplastic lesions, higher mortality rate and stronger weight loss than wild-type littermates (Antoch et al. 2008). Overall, these results suggest that a proper functioning of the circadian system and its underlying molecular components is protective against age-related degeneration.

Animal studies lend support to the involvement of the circadian system in age-related changes in neurobehavioral functions. For example, circadian disruption impairs various aspects of cognition in rats (Fekete et al. 1985, Craig and McDonald 2008) and more particularly so in aged animals (Antoniadis et al. 2000). Also, treatment of a mouse model of Huntington's disease (a neurodegenerative disorder) improves the expression of Per 2 in combination with slowing cognitive decrement (Pallier et al. 2007). Notably, recent data suggest that the link between ageing and circadian rhythms could reside in the circadian regulation by nitric oxide, whose levels are greatly reduced with ageing (Kunieda et al. 2008). As well, inhibition of nitric oxide synthase activity leads to modifications in clock gene expression in aorta (Kunieda et al. 2008), this association could also explain the age-related susceptibility in cardiovascular disease since nitric oxide is a main regulator of the cardiovascular biology. Finally, the relationship between clock genes and neuronal or cellular health throughout ageing could be mediated by the control of the length of chromosome extremities (telomere), which could virtually indicate a role for circadian regulation of ageing in every cells of the organism, as suggested by a recent study (Qu et al. 2008). 


\section{CONCLUSION AND PERSPECTIVES}

In conclusion, the molecular biology of circadian rhythms is involved in a wide variety of homeostatic functions in mammals and is of particular relevance to human health (Fig. 1). This molecular system does not only regulate various aspects of health but is also highly responsive to alterations in internal biology. It is increasingly obvious that elements identified as the molecular clock components - clock genes - do not only orchestrate animal physiology in relation to environmental light-dark cycle but also allow appropriate response to internal changes in physiology. Numerous example of such bidirectional regulation between the circadian clock and other physiological systems have been described in the present review. For instance, while the behavioral and biochemical effects of drug of abuse show a timedependent response, the exposure to these substances modifies considerably the molecular regulation of clock genes. Another example is that normal molecular circadian organization seems required for appropriate anti-cancer protection but the occurrence of cancer generates considerable circadian disruption. In some cases, such bidirectional influences might exacerbate states of health that are already damaged. Accordingly, it might be of importance to consider clock genes as regulatory genes and/or early response genes and to assess their regulation on a routine basis in health research and treatment.

\section{ACKNOWLEDGEMENTS}

V. M. has been supported by fellowships from the Fonds de la Recherche en Santé du Québec (FRSQ) and Natural Science and Engineering Research Council (NSERC, Canada) and N. C. by an FRSQ salary award. Research in N. C.'s laboratory is supported by NSERC and the Canadian Institutes for Health Research.

\section{REFERENCES}

Abe M, Herzog ED, Yamazaki S, Straume M, Tei H, Sakaki Y, Menaker M, Block GD: Circadian rhythms in isolated brain regions. J. Neurosci. 22:350-356, 2002.

Akashi M. Takumi T: The orphan nuclear receptor ROR $\alpha$ regulated circadian transcription of the mammalian core-clock Bmall. Nat. Struct. Mol. Biol. 12:441-448, 2005.
Akhisaroglu M, Ahmed R, Kurtuncu M, Manev H, Uz $\mathrm{T}$ : Diurnal rhythms in cocaine sensitization and in Period1 levels are common across rodent species. Pharmacol. Biochem. Behav. 79:37-42, 2004.

Alenghat T, Meyers K, Mullican SE, Leitner K, Adeniji-Adele A, Avila J, Bućan M, Ahima RS, Kaestner KH, Lazar MA: Nuclear receptor corepressor and histone deacetylase 3 govern circadian metabolic physiology. Nature 456:997-1000, 2008.

Alvarez JD, Hansen A, Ord T, Bebas P, Chappell PE, Giebultowicz JM, Williams C, Moss S, Sehgal A: The circadian clock protein BMAL1 is necessary for fertility and proper testosterone production in mice. J. Biol. Rhythms 23:26-36, 2008.

American Academy of Sleep Medicine (AASM): International Classification of Sleep Disorders, $2^{\text {nd }}$ edn. Diagnostic and Coding Manual. American Academy of Sleep Medicine; Westchester 2005.

Andreas S, Eichele G: Sleep apnoea: time to consider clock genes. Eur. Respir. J. 32:1-2, 2008.

Angeles-Castellanos M, Salgado-Delgado R, Rodríguez K, Buijs RM, Escobar C: Expectancy for food or expectancy for chocolate reveals timing systems for metabolism and reward. Neuroscience 155:297-307, 2008.

Antoch MP, Gorbacheva VY, Vykhovanets O, Toshkov IA, Kondratov RV, Kondratova AA, Lee C, Nikitin AY: Disruption of the circadian clock due to the Clock mutation has discrete effects on aging and carcinogenesis. Cell Cycle 7:1197-1204, 2008.

Antoniadis EA, Ko CH, Ralph MR, McDonald RJ: Circadian rhythms, aging and memory. Behav. Brain Res. 114:221-233, 2000.

Archer SN, Robilliard DL, Skene DJ, Smits M, Williams A, Arendt J, von Schantz M: A length polymorphism in the circadian clock gene Per3 is linked to delayed sleep phase syndrome and extreme diurnal preference. Sleep 26:413-415, 2003.

Arjona A, Sarkar DK: The circadian gene mPer2 regulates the daily rhythm of IFN-gamma. J. Interferon Cytokine Res. 26:645-649, 2006.

Azama T, Yano M, Oishi K, Kadota K, Hyun K, Tokura H, Nishimura S, Matsunaga T, Iwanaga $\mathrm{H}$, Miki H, Okada K, Hiraoka N, Miyata $\mathrm{H}$, Takiguchi S, Fujiwara Y, Yasuda T, Ishida N, Monden M: Altered expression profiles of clock genes hPerl and hPer2 in peripheral blood mononuclear cells of cancer patients undergoing surgery. Life Sci. 80:1100-1108, 2007.

Barnard AR, Nolan PM: When clocks go bad: neurobehavioural consequences of disrupted circadian timing. PLoS Genet. 4:e1000040, 2008. 
Berger J: Advances in chronohaematology. J. Appl. Biomed. 6:65-72, 2008.

Biggi N, Consonni D, Galluzzo V, Sogliani M, Costa G: Metabolic syndrome in permanent night workers. Chronobiol. Int. 25:443-454, 2008.

Boggild H, Knutsson A: Shift work, risk factors and cardiovascular disease. Scand. J. Work Environ. Health 25:85-99, 1999.

Bookout AL, Jeong Y, Downes M, Yu RT, Evans RM, Mangelsdorf DJ: Anatomical profiling of nuclear receptor expression reveals a hierarchical transcriptional network. Cell 126:789-799, 2006.

Born J, Lange T, Hansen K, Mölle M, Fehm HL: Effects of sleep and circadian rhythm on human circulating immune cells. J. Immunol. 158:4454-4464, 1997.

Buja A, Mastrangelo G, Perissinotto E, Grigoletto F, Frigo AC, Rausa G, Marin V, Canova C, Dominici $\mathrm{F}$ : Cancer incidence among female flight attendants: a meta-analysis of published data. J. Womens Health (Larchmt) 15:98-105, 2006.

Burioka N, Koyanagi S, Endo M, Takata M, Fukuoka Y, Miyata M, Takeda K, Chikumi H, Ohdo S, Shimizu E: Clock gene dysfunction in patients with obstructive sleep apnoea syndrome. Eur. Respir. J. 32:105-112, 2008.

Cajochen C, Munch M, Knoblauch V, Blatter K, Wirz-Justice A: Age related changes in the circadian and homeostatic regulation of human sleep. Chronobiol. Int. 23:461-474, 2006.

Carpen JD, Archer SN, Skene DJ, Smits M, von Schantz M: A single-nucleotide polymorphism in the 5'-untranslated region of the hPER2 gene is associated with diurnal preference. J. Sleep Res. 14:293-297, 2005.

Carpen JD, von Schantz M, Smits M, Skene DJ, Archer SN: A silent polymorphism in the PER1 gene associates with extreme diurnal preference in humans. J. Hum. Genet. 51:1122-1125, 2006.

Cavadini G, Petrzilka S, Kohler P, Jud C, Tobler I, Birchler T, Fontana A: TNF- $\alpha$ suppresses the expression of clock genes by interfering with Ebox-mediated transcription. Proc. Natl. Acad. Sci. U.S.A. 104:12843-12848, 2007.

Cermakian N, Boivin DB: A molecular perspective of human circadian rhythm disorders. Brain Res. Rev. 42:204-220, 2003.

Cermakian N, Sassone-Corsi P: Environmental stimulus perception and control of circadian clocks. Curr. Opin. Neurobiol. 12:359-365, 2002.

Chen ST, Choo KB, Hou MF, Yeh KT, Kuo SJ, Chang JG: Deregulated expression of the PER1, PER2 and PER3 genes in breast cancers. Carcinogenesis 26:1241-1246, 2005.
Chen Z, McKnight SL: A conserved DNA damage response pathway responsible for coupling the cell division cycle to the circadian and metabolic cycles. Cell Cycle 6:2906-2912, 2007.

Copertaro A, Bracci M, Barbaresi M, Santarelli L: Assessment of cardiovascular risk in shift healthcare workers. Eur. J. Cardiovasc. Prev. Rehabil. 15:224-229, 2008.

Costa G: The impact of shift and night work on health. Appl. Ergon. 27:9-16, 1996.

Craig LA, McDonald RJ: Chronic disruption of circadian rhythms impairs hippocampal memory in the rat. Brain Res. Bull. 76:141-151, 2008.

Cutolo M, Seriolo B, Craviotto C, Pizzorni C, Sulli A: Circadian rhythms in RA. Ann. Rheum. Dis. 62:593-596, 2003.

Dagenais-Bellefeuille S, Bertomeu T, Morse D: Sphase and M-phase timing are under independent circadian control in the dinoflagellate Lingulodinium. J. Biol. Rhythms 23:400-408, 2008.

Damiola F, Le Minh N, Preitner N, Kornmann B, Fleury-Olela F, Schibler U: Restricted feeding uncouples circadian oscillators in peripheral tissues from the central pacemaker in the suprachiasmatic nucleus. Genes Dev. 14:2950-2961, 2000.

Dardente H, Cermakian N: Molecular circadian rhythms in central and peripheral clocks in mammals. Chronobiol Int. 24:195-213, 2007.

Dardente H, Fortier EE, Martineau V, Cermakian N: Cryptochromes impair phosphorylation of transcriptional activators in the clock: a general mechanism for circadian repression. Biochem. J. 402:525-536, 2007.

Davidson AJ, Yamazaki S, Arble DM, Menaker M, Block GD: Resetting of central and peripheral circadian oscillators in aged rats. Neurobiol. Aging 29:471-477, 2008.

Davis S, Mirick DK, Stevens RG: Night shift work, light at night, and risk of breast cancer. J. Natl. Cancer Inst. 93:1557-1562, 2001.

Debruyne JP, Noton E, Lambert CM, Maywood ES, Weaver DR, Reppert SM: A clock shock: mouse CLOCK is not required for circadian oscillator function. Neuron 50:465-477, 2006.

DeBruyne JP, Weaver DR, Reppert SM: CLOCK and NPAS2 have overlapping roles in the suprachiasmatic circadian clock. Nat. Neurosci. 10:543-545, 2007.

Dolatshad H, Campbell EA, O'Hara L, Maywood ES, Hastings MH, Johnson MH: Developmental and reproductive performance in circadian mutant mice. Hum. Reprod. 21:68-79, 2006.

Dudley CA, Erbel-Sieler C, Estill SJ, Reick M, 
Franken P, Pitts S, McKnight SL: Altered patterns of sleep and behavioral adaptability in NPAS2deficient mice. Science 301:379-383, 2003.

Duez H, Staels B: Rev-erb alpha gives a time cue to metabolism. FEBS Lett. 582:19-25, 2008.

Duez H, Veen JV, Duhem C, Pourcet B, Touvier T, Fontaine C, Derudas B, Baugé E, Havinga R, Bloks VW, Wolters $H$, van der Sluijs FH, Vennström B, Kuipers F, Staels B: Regulation of Bile Acid Synthesis by the Nuclear Receptor Reverbalpha. Gastroenterology 135:689-698 2008.

Duffield GE: DNA microarray analyses of circadian timing: the genomic basis of biological time. J. Neuroendocrinol. 15:991-1002, 2003.

Dunlap JC, Loros JJ, DeCoursey PJ: Chronobiology: Biological Timekeeping. Sinauer Associates, Sunderland 2004.

Durgan DJ, Trexler NA, Egbejimi O, McElfresh TA, Suk HY, Petterson LE, Shaw CA, Hardin PE, Bray MS, Chandler MP, Chow CW, Young ME: The circadian clock within the cardiomyocyte is essential for responsiveness of the heart to fatty acids. J. Biol. Chem. 281:24254-24269, 2006.

Eksik A, Akyol A, Norgaz T, Aksu H, Erdinler I, Cakmak N, Alper AT, Cinar B, Yildirim A, Gürkan K: Circadian pattern of spontaneous ventricular tachyarrhythmias in patients with implantable cardioverter defibrillators. Med. Sci. Monit. 13:CR412-416, 2007.

Ellingsen T, Bener A, Gehani AA: Study of shift work and risk of coronary events. J. R. Soc. Health 127:265-267, 2007.

Fekete M, van Ree JM, Niesink RJ, de Wied D: Disrupting circadian rhythms in rats induces retrograde amnesia. Physiol. Behav. 34:883-887, 1985.

Filipski E, King VM, Li X, Granda TG, Mormont MC, Liu X, Claustrat B, Hastings MH, Lévi F: Host circadian clock as a control point in tumor progression. J. Natl. Cancer Inst. 94:690-697, 2002.

Filipski E, King VM, Li X, Granda TG, Mormont MC, Claustrat B, Hastings MH, Lévi F: Disruption of circadian coordination accelerates malignant growth in mice. Pathol. Biol. (Paris) 51:216-219, 2003.

Filipski E, Delaunay F, King VM, Wu MW, Claustrat B, Gréchez-Cassiau A, Guettier C, Hastings MH, Francis L: Effects of chronic jet lag on tumor progression in mice. Cancer Res. 64:7879-7885, 2004.

Filipski E, Innominato PF, Wu M, Li XM, Iacobelli S, Xian LJ, Lévi F: Effects of light and food schedules on liver and tumor molecular clocks in mice. J. Natl. Cancer Inst. 97:507-517, 2005.
Fontaine C, Staels B: The orphan nuclear receptor Rev-erbo: a transcriptional link between circadian rhythmicity and cardiometabolic disease. Curr. Opin. Lipidol. 18:141-146, 2007.

Franken P, Dudley CA, Estill SJ, Barakat M, Thomason R, O'Hara BF, McKnight SL: NPAS2 as a transcriptional regulator of non-rapid eye movement sleep: genotype and sex interactions. Proc. Natl. Acad. Sci. U.S.A. 103:7118-7123, 2006.

Franken P, Thomason R, Heller HC, O'Hara BF: A non-circadian role for clock-genes in sleep homeostasis: a strain comparison. BMC Neurosci. 8:87, 2007.

Fu L, Pelicano H, Liu J, Huang P, Lee C: The circadian gene Period 2 plays an important role in tumor suppression and DNA damage response in vivo. Cell 111:41-50, 2002.

Fu L, Patel MS, Bradley A, Wagner EF, Karsenty G: The molecular clock mediates leptin-regulated bone formation. Cell 122:803-815, 2005.

Gallego M, Kang H, Virshup DM: Protein phosphatase 1 regulates the stability of the circadian protein PER2. Biochem. J. 399:169-175, 2006.

Gallego M, Virshup DM: Post-translational modifications regulate the ticking of the circadian clock. Nat. Rev. Mol. Cell Biol. 8:139-148, 2007.

Gatfield D, Schibler U: Circadian glucose homeostasis requires compensatory interference between brain and liver clocks. Proc. Natl. Acad. Sci. U.S.A. 105:14753-14754, 2008.

Gauger MA, Sancar A: Cryptochrome, circadian cycle, cell cycle checkpoints, and cancer. Cancer Res. 65:6828-6834, 2005.

Gekakis N, Staknis D, Nguyen HB, Davis FC, Wilsbacher LD, King DP, Takahashi JS, Weitz CJ: Role of the CLOCK protein in the mammalian circaidian mechanism. Science 280:1564-1569, 1998.

Gery S, Komatsu N, Baldjyan L, Yu A, Koo D, Koeffler HP: The circadian gene Perl plays an important role in cell growth and DNA damage control in human cancer cells. Mol. Cell 22:375-382, 2006.

Gomez-Abellán P, Hernández-Morante JJ, Luján JA, Madrid JA, Garaulet M: Clock genes are implicated in the human metabolic syndrome. Int. J. Obes. (Lond.) 32:121-128, 2008.

Gorbacheva VY, Kondratov RV, Zhang R, Cherukuri S, Gudkov AV, Takahashi JS, Antoch MP: Circadian sensitivity to the chemotherapeutic agent cyclophosphamide depends on the functional status of the CLOCK/BMAL1 
transactivation complex. Proc. Natl. Acad. Sci. U.S.A. 102:3407-3412, 2005.

Granados-Fuentes D, Saxena MT, Prolo LM, Aton SJ, Herzog ED: Olfactory bulb neurons express functional, entrainable circadian rhythms. Eur. J. Neurosci. 19:898-906, 2004.

Granda TG, Liu XH, Smaaland R, Cermakian N, Filipski E, Sassone-Corsi P, Lévi F: Circadian regulation of cell cycle and apoptosis proteins in mouse bone marrow and tumor. FASEB J. 19:304-306, 2005.

Gréchez-Cassiau A, Panda S, Lacoche S, Teboul M, Azmi S, Laudet V, Hogenesch JB, Taneja R, Delaunay $F$ : The transcriptional repressor STRA13 regulates a subset of peripheral circadian outputs. J. Biol. Chem. 279:1141-1150, 2004.

Gréchez-Cassiau A, Rayet B, Guillaumond F, Teboul M, Delaunay F: The circadian clock component BMAL1 is a critical regulator of $p 21^{\text {WAFI/CIPI }}$ expression and hepatocyte proliferation. J. Biol. Chem. 283:4535-4542, 2008.

Guillaumond F, Dardente H, Giguere V, Cermakian $\mathrm{N}$ : Differential control of Bmall circadian transcription by REV-ERB and ROR nuclear receptors. J. Biol. Rhythms 20:391-403, 2005.

Hamaguchi H, Fujimoto K, Kawamoto T, Noshiro M, Maemura K, Takeda N, Nagai R, Furukawa M, Honma S, Honma K, Kurihara H, Kato Y: Expression of the gene for Dec2, a basic helixloop-helix transcription factor, is regulated by a molecular clock system. Biochem. J. 382:43-50, 2004.

Hampp G, Ripperger JA, Houben T, Schmutz I, Blex C, Perreau-Lenz S, Brunk I, Spanagel R, AhnertHilger G, Meijer JH, Albrecht U: Regulation of monoamine oxidase a by circadian-clock components implies clock influence on mood. Curr. Biol. 18:678-683, 2008.

Hansen J: Light at night, shiftwork, and breast cancer risk. J. Natl. Cancer Inst. 93:1513-1515, 2001.

Harper DG, Stopa EG, Kuo-Leblanc V, McKee AC, Asayama K, Volicer L, Kowall N, Satlin A: Dorsomedial SCN neuronal subpopulations subserve different functions in human dementia. Brain 131:1609-1617, 2008.

Hastings MH, Herzog ED: Clock genes, oscillators, and cellular networks in the suprachiasmatic nuclei. J. Biol. Rhythms. 19:400-413, 2004.

Haupt CM, Alte D, Dörr M, Robinson DM, Felix SB, John U, Völzke H: The relation of exposure to shift work with atherosclerosis and myocardial infarction in a general population. Atherosclerosis 201: 205-211, 2008

Hayashi M, Shimba S, Tezuka M: Characterization of the molecular clock in mouse peritoneal macrophages. Biol. Pharm. Bull. 30:621-626, 2007.

Hoffman AE, Zheng T, Ba Y, Zhu Y: The circadian gene NPAS2, a putative tumor suppressor, is involved in DNA damage response. Mol. Cancer Res. 6:1461-1468, 2008.

Holmbäck U, Forslund A, Forslund J, Hambraeus L, Lennernäs M, Lowden A, Stridsberg M, Akerstedt $\mathrm{T}$ : Metabolic responses to nocturnal eating in men are affected by sources of dietary energy. J. Nutr. 132:1892-1899, 2002.

Hriscu ML: Modulatory factors of circadian phagocytic activity. Ann. N. Y. Acad. Sci. 1057:403-430, 2005.

Inoue I, Shinoda Y, Ikeda M, Hayashi K, Kanazawa $\mathrm{K}$, Nomura $\mathrm{M}$, Matsunaga $\mathrm{T}, \mathrm{Xu} \mathrm{H}$, Kawai S, Awata T, Komoda T, Katayama S: CLOCK/BMAL1 is involved in lipid metabolism via transactivation of the peroxisome proliferatoractivated receptor (PPAR) response element. J. Atheroscler. Thromb. 12:169-174, 2005.

Iurisci I, Filipski E, Reinhardt J, Bach S, GianellaBorradori A, Iacobelli S, Meijer L, Lévi F: Improved tumor control through circadian clock induction by Seliciclib, a cyclin-dependent kinase inhibitor. Cancer Res. 66:10720-10728, 2006.

Iwase T, Kajimura N, Uchiyama M, Ebisawa T, Yoshimura K, Kamei Y, Shibui K, Kim K, Kudo Y, Katoh M, Watanabe T, Nakajima T, Ozeki Y, Sugishita M, Hori T, Ikeda M, Toyoshima R, Inoue $\mathrm{Y}$, Yamada $\mathrm{N}$, Mishima $\mathrm{K}$, Nomura $\mathrm{M}$, Ozaki N, Okawa M, Takahashi K, Yamauchi T: Mutation screening of the human Clock gene in circadian rhythm sleep disorders. Psychiatry Res. 109:121-128, 2002.

Johansson C, Willeit M, Smedh C, Ekholm J, Paunio T, Kieseppä T, Lichtermann D, Praschak-Rieder N, Neumeister A, Nilsson LG, Kasper S, Peltonen $\mathrm{L}$, Adolfsson R, Schalling M, Partonen T: Circadian clock-related polymorphisms in seasonal affective disorder and their relevance to diurnal preference. Neuropsychopharmacology 28:734-739, 2003.

Jones KH, Ellis J, von Schantz M, Skene DJ, Dijk DJ, Archer SN: Age-related change in the association between a polymorphism in the PER3 gene and preferred timing of sleep and waking activities. J. Sleep Res. 16:12-16, 2007.

Kang HS, Angers M, Beak JY, Wu X, Gimble JM, Wada T, Xie W, Collins JB, Grissom SF, Jetten AM: Gene expression profiling reveals a regulatory role for $\mathrm{ROR} \alpha$ and $\mathrm{ROR} \gamma$ in phase I and phase II metabolism. Physiol. Genomics 31:281-294, 2007.

Katzenberg D, Young T, Finn L, Lin L, King DP, 
Takahashi JS, Mignot E: A CLOCK polymorphism associated with human diurnal preference. Sleep 21:569-576, 1998.

Kawakami C, Ohshige K, Tochikubo O: Circadian variation in cardiovascular emergencies among the elderly. Clin. Exp. Hypertens. 30:23-31, 2008.

Kennaway DJ, Owens JA, Voultsios A, Boden MJ, Varcoe TJ: Metabolic homeostasis in mice with disrupted Clock gene expression in peripheral tissues. Am. J. Physiol. Regul. Integr. Comp. Physiol. 293:R1528-R1537, 2007.

Kloog I, Haim A, Stevens RG, Barchana M, Portnov BA: Light at night co-distributes with incident breast but not lung cancer in the female population of Israel. Chronobiol. Int. 25:65-81, 2008.

Kondratov RV, Kondratova AA, Gorbacheva VY, Vykhovanets OV, Antoch MP: Early aging and age-related pathologies in mice deficient in BMAL1, the core component of the circadian clock. Genes Dev. 20:1868-1873, 2006.

Kornmann B, Schaad O, Bujard H, Takahashi JS, Schibler U: System-driven and oscillatordependent circadian transcription in mice with a conditionally active liver clock. PLoS Biol. 5:e34, 2007.

Kosobud AE, Gillman AG, Leffel JK $2^{\text {nd }}$, Pecoraro NC, Rebec GV, Timberlake W: Drugs of abuse can entrain circadian rhythms. ScientificWorldJournal 7:203-212, 2007.

Kudo T, Kawashima M, Tamagawa T, Shibata S: Clock mutation facilitates accumulation of cholesterol in the liver of mice fed a cholesterol and/or cholic acid diet. Am. J. Physiol. Endocrinol. Metab. 294:E120-E130, 2008.

Kume K, Zylka MJ, Sriram S, Shearman LP, Weaver DR, Jin X, Maywood ES, Hastings MH, Reppert SM: mCRY1 and mCRY2 are essential components of the negative limb of the circadian clock feedback loop. Cell 98:193-205, 1999.

Kunieda T, Minamino T, Miura K, Katsuno T, Tateno $\mathrm{K}$, Miyauchi $\mathrm{H}$, Kaneko S, Bradfield CA, FitzGerald GA, Komuro I: Reduced nitric oxide causes age-associated impairment of circadian rhythmicity. Circ. Res. 102:607-614, 2008.

Kurebayashi S, Ueda E, Sakaue M, Patel DD, Medvedev A, Zhang F, Jetten AM: Retinoidrelated orphan receptor gamma $(\mathrm{ROR} \gamma)$ is essential for lymphoid organogenesis and controls apoptosis during thymopoiesis. Proc. Natl. Acad. Sci. U.S.A. 97:10132-10137, 2000.

Lamia KA, Storch KF, Weitz CJ: Physiological significance of a peripheral tissue circadian clock. Proc. Natl. Acad. Sci. U.S.A 105:15172-15177, 2008.
Lamont EW, Robinson B, Stewart J, Amir S: The central and basolateral nuclei of the amygdala exhibit opposite diurnal rhythms of expression of the clock protein Period2. Proc. Natl. Acad. Sci. U.S.A. 102:4180-4184, 2005.

Lamont EW, Legault-Coutu D, Cermakian N, Boivin DB: The role of circadian clock genes in mental disorders. Dialogues Clin. Neurosci. 9:333-342, 2007.

Lau P, Nixon SJ, Parton RG, Muscat GE: ROR $\alpha$ regulates the expression of genes involved in lipid homeostasis in skeletal muscle cells: caveolin-3 and CPT-1 are direct targets of ROR. J. Biol. Chem. 279:36828-36840, 2004.

Lee CC: Tumor suppression by the mammalian Period genes. Cancer Causes Control. 17:525-530, 2006.

Lennernäs M, Akerstedt T, Hambraeus L: Nocturnal eating and serum cholesterol of three-shift workers. Scand. J. Work Environ. Health 20:401-406, 1994.

Lévi F, Filipski E, Iurisci I, Li XM, Innominato P: Cross-talks between circadian timing system and cell division cycle determine cancer biology and therapeutics. Cold Spring Harb. Symp. Quant. Biol. 72:465-475, 2007.

Lévi F, Altinok A, Clairambault J, Goldbeter A: Implications of circadian clocks for the rhythmic delivery of cancer therapeutics. Philos. Transact. A. Math. Phys. Eng. Sci. 366:3575-3598, 2008.

Liu J, Malkani G, Shi X, Meyer M, CunninghamRunddles S, Ma X, Sun ZS: The circadian clock Period 2 gene regulates gamma interferon production of NK cells in host response to lipopolysaccharide-induced endotoxic shock. Infect. Immun. 74:4750-4756, 2006.

Liu AC, Welsh DK, Ko CH, Tran HG, Zhang EE, Priest AA, Buhr ED, Singer O, Meeker K, Verma IM, Doyle FJ $3^{\text {rd }}$, Takahashi JS, Kay SA: Intercellular coupling confers robustness against mutations in the SCN circadian clock network. Cell 129:605-616, 2007a.

Liu C, Li S, Liu T, Borjigin J, Lin JD: Transcriptional coactivator PGC-1alpha integrates the mammalian clock and energy metabolism. Nature 447:477-481, 2007b.

Lowrey PL, Takahashi JS: Genetics of the mammalian circadian system: Photic entrainment, circadian pacemaker mechanisms, and posttranslational regulation. Annu. Rev. Genet. 34:533-562, 2000.

Lynch WJ, Girgenti MJ, Breslin FJ, Newton SS, Taylor JR: Gene profiling the response to repeated cocaine self-administration in dorsal striatum: a focus on circadian genes. Brain Res. 1213:166-177, 2008. 
Martino TA, Tata N, Belsham DD, Chalmers J, Straume M, Lee P, Pribiag H, Khaper N, Liu PP, Dawood F, Backx PH, Ralph MR, Sole MJ: Disturbed diurnal rhythm alters gene expression and exacerbates cardiovascular disease with rescue by resynchronization. Hypertension 49:1104-1113, 2007.

Martino TA, Oudit GY, Herzenberg AM, Tata N, Koletar MM, Kabir GM, Belsham DD, Backx PH, Ralph MR, Sole MJ: Circadian rhythm disorganization produces profound cardiovascular and renal disease in hamsters. Am. J. Physiol. Regul. Integr. Comp. Physiol. 294:R1675-R1683, 2008.

Matsuo T, Yamaguchi S, Mitsui S, Emi A, Shimoda $\mathrm{F}$, Okamura $\mathrm{H}$ : Control mechanism of the circadian clock for timing of cell division in vivo. Science 302:255-259, 2003.

McClung CA, Sidiropoulou K, Vitaterna M, Takahashi JS, White FJ, Cooper DC, Nestler EJ: Regulation of dopaminergic transmission and cocaine reward by the Clock gene. Proc. Natl. Acad. Sci. U.S.A. 102:9377-9381, 2005.

McClung CA: Role for the Clock gene in bipolar disorder. Cold Spring Harb. Symp. Quant. Biol. 72:637-644, 2007a.

McClung CA: Circadian rhythms, the mesolimbic dopaminergic circuit, and drug addiction. ScientificWorldJournal 7:194-202, 2007b.

Méndez-Ferrer S, Lucas D, Battista M, Frenette PS: Haematopoietic stem cell release is regulated by circadian oscillations. Nature 452:442-447, 2008.

Meng QJ, Logunova L, Maywood ES, Gallego M, Lebiecki J, Brown TM, Sládek M, Semikhodskii AS, Glossop NR, Piggins HD, Chesham JE, Bechtold DA, Yoo SH, Takahashi JS, Virshup DM, Boot-Handford RP, Hastings MH, Loudon AS: Setting clock speed in mammals: the CK1g tau mutation in mice accelerates circadian pacemakers by selectively destabilizing PERIOD proteins. Neuron 58:78-88, 2008.

Miller BH, Olson SL, Turek FW, Levine JE, Horton TH, Takahashi JS: Circadian clock mutation disrupts estrous cyclicity and maintenance of pregnancy. Curr. Biol. 14:1367-1373, 2004.

Miller BH, Olson SL, Levine JE, Turek FW, Horton TH, Takahashi JS: Vasopressin regulation of the proestrous luteinizing hormone surge in wild-type and Clock mutant mice. Biol. Reprod. 75:778-784, 2006.

Miller BH, McDearmon EL, Panda S, Hayes KR, Zhang J, Andrews JL, Antoch MP, Walker JR, Esser KA, Hogenesch JB, Takahashi JS: Circadian and CLOCK-controlled regulation of the mouse transcriptome and cell proliferation. Proc. Natl. Acad. Sci. U.S.A. 104:3342-3347, 2007.
Mongrain V, Ruan X, Dardente H, Fortier EE, Cermakian N: Clock-dependent and independent transcriptional control of the two isoforms from the mouse Ror $\gamma$ gene. Genes Cells 13:1197-1210, 2008.

Mormont MC, Waterhouse J, Bleuzen P, Giacchetti S, Jami A, Bogdan A, Lellouch J, Misset JL, Touitou Y, Lévi F: Marked 24-h rest/activity rhythms are associated with better quality of life, better response, and longer survival in patients with metastatic colorectal cancer and good performance status. Clin. Cancer Res. 6:3038-3045, 2000.

Morse D, Cermakian N, Brancorsini S, Parvinen M, Sassone-corsi P: No circadian rhythms in testis: Period1 expression is Clock independent and developmentally regulated in the mouse. Mol. Endocrinol. 17:141-151, 2003.

Motzkus D, Albrecht U, Maronde E: The human PER1 gene is inducible by interleukin-6. J. Mol. Neurosci. 18:105-109, 2002.

Muller JE, Tofler GH, Willich SN, Stone PH: Circadian variation of cardiovascular disease and sympathetic activity. J. Cardiovasc. Pharmacol. 10:S104-S109, 1987.

Naito Y, Tsujino T, Kawasaki D, Okumura T, Morimoto S, Masai M, Sakoda T, Fujioka Y, Ohyanagi M, Iwasaki T: Circadian gene expression of clock genes and plasminogen activator inhibitor-1 in heart and aorta of spontaneously hypertensive and Wistar-Kyoto rats. J. Hypertens. 21:1107-1115, 2003.

Nakahata Y, Akashi M, Trcka D, Yasuda A, Takumi $\mathrm{T}$ : The in vitro real-time oscillation monitoring system identifies potential entrainment factors for circadian clocks. BMC Mol. Biol. 7:5, 2006.

Nakamura K, Inoue I, Takahashi S, Komoda T, Katayama S: Cryptochrome and period proteins are regulated by the CLOCK/BMAL1 gene: crosstalk between the PPARs/RXR $\alpha$-regulated and CLOCK/BMAL1-regulated systems. PPAR Res. 348610, 2008.

Nakashima A, Kawamoto T, Honda KK, Ueshima T, Noshiro M, Iwata T, Fujimoto K, Kubo H, Honma S, Yorioka N, Kohno N, Kato Y: DEC1 modulates the circadian phase of clock gene expression. Mol. Cell Biol. 28:4080-4092, 2008.

Naylor E, Bergmann BM, Krauski K, Zee PC, Takahashi JS, Vitaterna MH, Turek FW: The circadian clock mutation alters sleep homeostasis in the mouse. J. Neurosci. 20:8138-8143, 2000.

Ohkura N, Oishi K, Sudo T, Hayashi H, Shikata K, Ishida N, Matsuda J, Horie S: CLOCK regulates circadian platelet activity. Thromb. Res. 123:523-527, 2008.

Oishi K, Shirai H, Ishida N: CLOCK is involved in 
the circadian transactivation of peroxisomeproliferator-activated receptor alpha (PPARalpha) in mice. Biochem. J. 386:575-581, 2005.

Oishi K, Atsumi G, Sugiyama S, Kodomari I, Kasamatsu M, Machida K, Ishida N: Disrupted fat absorption attenuates obesity induced by a high-fat diet in Clock mutant mice. FEBS Lett. 580:127-130, 2006.

Okada K, Yano M, Doki Y, Azama T, Iwanaga H, Miki H, Nakayama M, Miyata H, Takiguchi S, Fujiwara Y, Yasuda T, Ishida N, Monden M: Injection of LPS causes transient suppression of biological clock genes in rats. J. Surg. Res. 145:5-12, 2008.

Otálora BB, Madrid JA, Alvarez N, Vicente V, Rol MA: Effects of exogenous melatonin and circadian synchronization on tumor progression in melanoma-bearing C57BL6 mice. J. Pineal Res. 44:307-315, 2008.

Paim SL, Pires ML, Bittencourt LR, Silva RS, Santos RF, Esteves AM, Barreto AT, Tufik S, de Mello MT. Sleep complaints and polysomnographic findings: a study of nuclear power plant shift workers. Chronobiol. Int. 25:321-331, 2008.

Pallier PN, Maywood ES, Zheng Z, Chesham JE, Inyushkin AN, Dyball R, Hastings MH, Morton AJ: Pharmacological imposition of sleep slows cognitive decline and reverses dysregulation of circadian gene expression in a transgenic mouse model of Huntington's disease. J. Neurosci. 27:7869-7878, 2007.

Panda S, Antoch MP, Miller BH, Su AI, Schook AB, Straume M, Schultz PG, Kay SA, Takahashi JS, Hogenesch JB: Coordinated transcription of key pathways in the mouse by the circadian clock. Cell 109:307-320, 2002.

Pedrazzoli M, Louzada FM, Pereira DS, BeneditoSilva AA, Lopez AR, Martynhak BJ, Korczak AL, Koike Bdel V, Barbosa AA, D'Almeida V, Tufik S: Clock polymorphisms and circadian rhythms phenotypes in a sample of the Brazilian population. Chronobiol. Int. 24:1-8, 2007.

Pereira DS, Tufik S, Louzada FM, Benedito-Silva AA, Lopez AR, Lemos NA, Korczak AL, D'Almeida V, Pedrazzoli M: Association of the length polymorphism in the human Per3 gene with the delayed sleep-phase syndrome: does latitude have an influence upon it? Sleep 28:29-32, 2005.

Perreau-Lenz S, Spanagel R: The effects of drugs of abuse on clock genes. Drug News Perspect. 21:211-217, 2008.

Pilorz V, Steinlechner S: Low reproductive success in Per1 and Per2 mutant mouse females due to accelerated ageing? Reproduction 135:559-568,
2008.

Portela LF, Rotenberg L, Waissmann W: Selfreported health and sleep complaints among nursing personnel working under $12 \mathrm{~h}$ night and day shifts. Chronobiol. Int. 21:859-870, 2004.

Preitner N, Daminola FL, Lopez-Molina L, Zakany J, Duboule D, Albrecht U, Schibler U: The orphan nuclear receptor REV-ERB $\alpha$ controls circadian transcription within the positive limb of the mammalian circadian oscillator. Cell 110:251-260, 2002.

Qu Y, Mao M, Li X, Liu Y, Ding J, Jiang Z, Wan C, Zhang L, Wang $\mathrm{Z}$, Mu D: Telomerase reconstitution contributes to resetting of circadian rhythm in fibroblasts. Mol. Cell Biochem. 313:11-18, 2008.

Rafnsson V, Tulinius H, Jónasson JG, Hrafnkelsson J: Risk of breast cancer in female flight attendants: a population-based study (Iceland). Cancer Causes Control. 12:95-101, 2001.

Ralph MR, Foster RG, Davis FC, Menaker M: Transplanted suprachiasmatic nucleus determines circadian period. Science 247:975-978, 1990.

Ramakrishnan SN, Lau P, Burke LJ, Muscat GE: Rev-erb $\beta$ regulates the expression of genes involved in lipid absorption in skeletal muscle cells: evidence for cross-talk between orphan nuclear receptors and myokines. J. Biol. Chem. 280:8651-8659, 2005.

Reick M, Garcia JA, Dudley C, McKnight SL: NPAS2: an analog of clock operative in the mammalian forebrain. Science 293:506-509, 2001.

Reiter RJ, Tan DX, Korkmaz A, Erren TC, Piekarski C, Tamura H, Manchester LC: Light at night, chronodisruption, melatonin suppression, and cancer risk: a review. Crit. Rev. Oncog. 13:303-328, 2007.

Reppert SM, Weaver DR: Coordination of circadian timing in mammals. Nature 418:935-941, 2002.

Robilliard DL, Archer SN, Arendt J, Lockley SW, Hack LM, English J, Leger D, Smits MG, Williams A, Skene DJ, Von Schantz M: The 3111 Clock gene polymorphism is not associated with sleep and circadian rhythmicity in phenotypically characterized human subjects. J. Sleep Res. 11:305-312, 2002.

Rudic RD, McNamara P, Curtis AM, Boston RC, Panda S, Hogenesch JB, Fitzgerald GA: BMAL1 and CLOCK, two essential components of the circadian clock, are involved in glucose homeostasis. PLoS Biol. 2:e377, 2004.

Sato TK, Panda S, Miraglia LJ, Reyes TM, Rudic RD, Mcnamara P, Naik KA, FitzGerald GA, Kay SA, 
Hogenesch JB: A functional genomics strategy reveals Rora as a component of the mammalian circadian clock. Neuron 43:527-537, 2004.

Sato TK, Yamada RG, Ukai H, Baggs JE, Miraglia LJ, Kobayashi TJ, Welsh DK, Kay SA, Ueda HR, Hogenesch JB: Feedback repression is required for mammalian circadian clock function. Nat. Genet. 38:312-319, 2006.

Schibler U, Ripperger J, Brown SA: Peripheral circadian oscillators in mammals: time and food. J. Biol. Rhythms 18:250-260, 2003.

Schwartz JR, Roth T: Shift work sleep disorder: burden of illness and approaches to management. Drugs 66:2357-2370, 2006.

Sephton SE, Sapolsky RM, Kraemer HC, Spiegel D: Diurnal cortisol rhythm as a predictor of breast cancer survival. J. Natl. Cancer Inst. 92:994-1000, 2000.

Shea SA, Hilton MF, Muller JE: Day/night pattern of myocardial infarction and sudden cardiac death. Interacting roles of the endogenous circadian system and behavioral triggers. In White WB (ed): Clinical Hypertension and Vascular Disease: Blood Pressure Monitoring in Cardiovascular Medicine and Therapeutics, $2^{\text {nd }}$ edn. Humana Press Inc, Totowa, 2007, pp. 253-291.

Shimba S, Ishii N, Ohta Y, Ohno T, Watabe Y, Hayashi M, Wada T, Aoyagi T, Tezuka M: Brain and muscle Arnt-like protein-1 (BMAL1), a component of the molecular clock, regulates adipogenesis. Proc. Natl. Acad. Sci. U.S.A. 102:12071-12076, 2005.

Shirai H, Oishi K, Ishida N: Bidirectional CLOCK/BMAL1-dependent circadian gene regulation by retinoic acid in vitro. Biochem. Biophys. Res. Commun. 351:387-391, 2006.

Shirai H, Oishi K, Kudo T, Shibata S, Ishida N: PPARalpha is a potential therapeutic target of drugs to treat circadian rhythm sleep disorders. Biochem. Biophys. Res. Commun. 357:679-682, 2007.

Siegel D, Black DM, Seeley DG, Hulley SB: Circadian variation in ventricular arrhythmias in hypertensive men. Am. J. Cardiol. 69:344-347, 1992.

Silver R, Schwartz WJ: The suprachiasmatic nucleus is a functionally heterogeneous timekeeping organ. Methods Enzymol. 393:451-465, 2005.

Sitzmann BD, Lemos DR, Ottinger MA, Urbanski $\mathrm{HF}$ : Effects of age on clock gene expression in the rhesus macaque pituitary gland. Neurobiol. Aging, 2008 [in press].

Sonoda J, Mehl IR, Chong LW, Nofsinger RR, Evans RM: PGC-1beta controls mitochondrial metabolism to modulate circadian activity, adaptive thermogenesis, and hepatic steatosis. Proc. Natl. Acad. Sci. U.SA. 104:5223-5228, 2007.

Storch KF, Lipan O, Leykin I, Viswanathan N, Davis FC, Wong WH, Weitz CJ: Extensive and divergent circadian gene expression in liver and heart. Nature 417:78-83, 2002.

Stratmann M, Schibler U: Properties, entrainment, and physiological functions of mammalian peripheral oscillators. J. Biol. Rhythms 21:494-506, 2006.

Su TC, Lin LY, Baker D, Schnall PL, Chen MF, Hwang WC, Chen CF, Wang JD: Elevated blood pressure, decreased heart rate variability and incomplete blood pressure recovery after a 12hour night shift work. J. Occup. Health 50:380-386, 2008.

Sudo N, Ohtsuka R: Fatigue complaints among female shift workers in a computer factory of Japan. J. Hum. Ergol. (Tokyo) 31:41-51, 2002.

Sun A, Unutmaz D, Zou Y, Sunshine MJ, Pierani A, Brenner-Morton S, Mebius RE, Littman DR: Requirement for ROR $\gamma$ in thymocyte survival and lymphoid organ development. Science 288: 2369-2373, 2000.

Sun Y, Yang Z, Niu Z, Peng J, Li Q, Xiong W, Langnas AN, Ma MY, Zhao Y: MOP3, a component of the molecular clock, regulates the development of $\mathrm{B}$ cells. Immunology 119:451-460, 2006.

Suzuki T, Sato F, Kondo J, Liu Y, Kusumi T, Fujimoto K, Kato Y, Sato T, Kijima H: Period is involved in the proliferation of human pancreatic MIA-PaCa 2 cancer cells by TNF- $\alpha$. Biomed. Res. 29:99-103, 2008.

Takano A, Uchiyama M, Kajimura N, Mishima K, Inoue Y, Kamei Y, Kitajima T, Shibui K, Katoh M, Watanabe T, Hashimotodani Y, Nakajima T, Ozeki Y, Hori T, Yamada N, Toyoshima R, Ozaki N, Okawa M, Nagai K, Takahashi K, Isojima Y, Yamauchi T, Ebisawa T: A missense variation in human casein kinase I epsilon gene that induces functional alteration and shows an inverse association with circadian rhythm sleep disorders. Neuropsychopharmacology 29:1901-1909, 2004.

Terazono H, Hamdan A, Matsunaga N, Hayasaka N, Kaji H, Egawa T, Makino K, Shigeyoshi Y, Koyanagi S, Ohdo S: Modulatory effects of 5fluorouracil on the rhythmic expression of circadian clock genes: a possible mechanism of chemotherapy-induced circadian rhythm disturbances. Biochem. Pharmacol. 75:1616-1622, 2008.

Toh KL, Jones CR, He Y, Eide EJ, Hinz WA, Virshup DM, Ptáček LJ, Fu YH: An hPer2 
phosphorylation site mutation in familial advanced sleep phase syndrome. Science 291:1040-1043, 2001.

Turek FW, Joshu C, Kohsaka A, Lin E, Ivanova G, McDearmon E, Laposky A, Losee-Olson S, Easton A, Jensen DR, Eckel RH, Takahashi JS, Bass J: Obesity and metabolic syndrome in circadian Clock mutant mice. Science 308:1043-1045, 2005.

Turek FW: From circadian rhythms to clock genes in depression. Int. Clin. Psychopharmacol. 22:S1-S8, 2007.

Ueda HR, Hayashi S, Chen W, Sano M, Machida M, Shigeyoshi Y, Iino M, Hashimoto S: System-level identification of transcriptional circuits underlying mammalian circadian clocks. Nat. Genet. 37:167-192, 2005.

Uz T, Ahmed R, Akhisaroglu M, Kurtuncu M, Imbesi M, Dirim Arslan A, Manev H: Effect of fluoxetine and cocaine on the expression of clock genes in the mouse hippocampus and striatum. Neuroscience 134:1309-1316, 2005.

Vanselow K, Vanselow JT, Westermark PO, Reischl S, Maier B, Korte T, Herrmann A, Herzel H, Schlosser A, Kramer A: Differential effects of PER2 phosphorylation: molecular basis for the human familial advanced sleep phase syndrome (FASPS). Genes Dev. 20:2660-2672, 2006.

Viola AU, Archer SN, James LM, Groeger JA, Lo JC, Skene DJ, von Schantz M, Dijk DJ: PER3 polymorphism predicts sleep structure and waking performance. Curr. Biol. 17:613-618, 2007.

Viola AU, James LM, Archer SN, Dijk DJ: PER3 polymorphism and cardiac autonomic control: effects of sleep debt and circadian phase. Am. J. Physiol. Heart Circ. Physiol. 295:H2156-H2163, 2008.

Virkkunen H, Härmä M, Kauppinen T, Tenkanen L: Shift work, occupational noise and physical workload with ensuing development of blood pressure and their joint effect on the risk of coronary heart disease. Scand. J. Work Environ. Health 33:425-434, 2007.

Viswambharan H, Carvas JM, Antic V, Marecic A, Jud C, Zaugg CE, Ming XF, Montani JP, Albrecht $\mathrm{U}$, Yang Z: Mutation of the circadian clock gene Per2 alters vascular endothelial function. Circulation 115:2188-2195, 2007.

Viswanathan AN, Hankinson SE, Schernhammer ES: Night shift work and the risk of endometrial cancer. Cancer Res. 67:10618-10622, 2007.

Wang J, Yin L, Lazar MA: The orphan nuclear receptor Rev-erb $\alpha$ regulates circadian expression of plasminogen activator inhibitor type 1 . J. Biol.
Chem. 281:33842-33848, 2006.

Wang N, Yang G, Jia Z, Zhang H, Aoyagi T, Soodvilai S, Symons JD, Schnermann JB, Gonzalez FJ, Litwin SE, Yang T: Vascular PPAR $\gamma$ controls circadian variation in blood pressure and heart rate through Bmal1. Cell Metab. 8:482-491, 2008.

Welsh DK, Yoo SH, Liu AC, Takahashi JS, Kay SA: Bioluminescence imaging of individual fibroblasts reveals persistent, independently phased circadian rhythms of clock gene expression. Curr. Biol. 14:2289-2295, 2004.

Wisor JP, O'Hara BF, Terao A, Selby CP, Kilduff TS, Sancar A, Edgar DM, Franken P: A role for cryptochromes in sleep regulation. BMC Neurosci. 3:20, 2002.

Wisor JP, Pasumarthi RK, Gerashchenko D, Thompson CL, Pathak S, Sancar A, Franken P, Lein ES, Kilduff TS: Sleep deprivation effects on circadian clock gene expression in the cerebral cortex parallel electroencephalographic differences among mouse strains. J. Neurosci. 28:7193-7201, 2008.

Wood PA, Du-Quiton J, You S, Hrushesky WJ: Circadian clock coordinates cancer cell cycle progression, thymidylate synthase, and 5fluorouracil therapeutic index. Mol. Cancer Ther. 5:2023-2033, 2006.

Woon PY, Kaisaki PJ, Bragança J, Bihoreau MT, Levy JC, Farrall M, Gauguier D: Aryl hydrocarbon receptor nuclear translocator-like (BMAL1) is associated with susceptibility to hypertension and type 2 diabetes. Proc. Natl. Acad. Sci. U.S.A. 104:14412-14417, 2007.

Xu Y, Padiath QS, Shapiro RE, Jones CR, Wu SC, Saigoh N, Saigoh K, Ptáček LJ, Fu YH: Functional consequences of a $C K I \delta$ mutation causing familial advanced sleep phase syndrome. Nature 434:640-644, 2005.

Xu Y, Toh KL, Jones CR, Shin JY, Fu YH, Ptáček LJ: Modeling of a human circadian mutation yields insights into clock regulation by PER2. Cell 128:59-70, 2007.

Yamazaki S, Numano R, Abe M, Hida A, Takahashi R, Ueda M, Block GD, Sakaki Y, Menaker M, Tei $\mathrm{H}$ : Resetting central and peripheral circadian oscillators in transgenic rats. Science 288:682-685, 2000.

Yamazaki S, Straume M, Tei H, Sakaki Y, Menaker M, Block GD: Effects of aging on central and peripheral mammalian clocks. Proc. Natl. Acad. Sci. U.S.A. 99:10801-10806, 2002.

Yang S, Van Dongen HP, Wang K, Berrettini W, 
Bućan M: Assessment of circadian function in fibroblasts of patients with bipolar disorder. Mol. Psychiatry 14:143-155, 2009.

Yang WS, Stockwell BR: Inhibition of casein kinase 1-epsilon induces cancer-cell-selective, PERIOD2-dependent growth arrest. Genome Biol. 9:R92, 2008.

Yang X, Downes M, Yu RT, Bookout AL, He W, Straume M, Mangelsdorf DJ, Evans RM: Nuclear receptor expression links the circadian clock to metabolism. Cell 126:801-810, 2006.

Yang X, Wood PA, Oh EY, Du-Quiton J, Ansell CM, Hrushesky WJ: Down regulation of circadian clock gene Period 2 accelerates breast cancer growth by altering its daily growth rhythm. Breast Cancer Res. Treat. 2008 [in press].

Yoo SH, Yamazaki S, Lowrey PL, Shimomura K, Ko CH, Buhr ED, Siepka SM, Hong HK, Oh WJ, Yoo OJ, Menaker M, Takahashi JS: PERIOD2::LUCIFERASE real-time reporting of circadian dynamics reveals persistent circadian oscillations in mouse peripheral tissues. Proc.
Natl. Acad. Sci. U.S.A. 101:5339-5346, 2004. You S, Wood PA, Xiong Y, Kobayashi M, Du-Quiton J, Hrushesky WJ: Daily coordination of cancer growth and circadian clock gene expression. Breast Cancer Res. Treat. 91:47-60, 2005.

Young MR, Matthews JP, Kanabrocki EL, Sothern RB, Roitman-Johnson B, Scheving LE: Circadian rhythmometry of serum interleukin-2, interleukin10 , tumor necrosis factor- $\alpha$, and granulocytemacrophage colony-stimulating factor in men. Chronobiol. Int. 12:19-27, 1995.

Young ME, Bray MS: Potential role for peripheral circadian clock dyssynchrony in the pathogenesis of cardiovascular dysfunction. Sleep Med. 8:656-667, 2007.

Zhu Y, Brown HN, Zhang Y, Stevens RG, Zheng T: Period3 structural variation: a circadian biomarker associated with breast cancer in young women. Cancer Epidemiol. Biomarkers Prev. 14:268-270, 2005. 